\title{
Pythium insidiosum: Morphological and molecular identification of Brazilian isolates ${ }^{1}$
}

\author{
Maria Isabel de Azevedo², Daniela I.B. Pereira ${ }^{3}$, Sônia A. Botton ${ }^{4}$, Mateus M. da Costa ${ }^{5}$, \\ Camila D. Mahl ${ }^{2}$, Sydney H. Alves ${ }^{2}$ and Janio M. Santurio ${ }^{2 *}$
}

\begin{abstract}
Azevedo M.I., Pereira D.I.B., Botton S.A., Costa M.M., Mahl C.D., Alves S.A. \& Santurio J.M. 2012. Pythium insidiosum: Morphological and molecular identification of Brazilian isolates. Pesquisa Veterinária Brasileira 32(7):619-622. Laboratório de Pesquisas Micológicas, Departamento de Microbiologia e Parasitologia, Universidade Federal de Santa Maria, Camobi, Santa Maria, RS 97105-900, Brazil. E-mail: janio.santurio@gmail.com

Pythium insidiosum is an oomycete belonging to the kingdom Stramenipila and it is the etiologic agent of pythiosis. Pythiosis is a life-threatening infectious disease characterized by the development of chronic lesions on cutaneous and subcutaneous, intestinal, and bone tissues in humans and many species of animals. The identification of $P$. insidiosum is important in order to implement a rapid and definitive diagnosis and an effective treatment. This study reports the identification of 54 isolates of $P$. insidiosum of horses, dogs and sheep that presented suspicious clinical lesions of pythiosis from different regions in Brazil, by using morphological and molecular assays. Throughout the PCR it was possible to confirm the identity of all Brazilian isolates as being $P$. insidiosum.
\end{abstract}

INDEX TERMS: Oomycete, identification, Pythium insidiosum, pythiosis.

RESUMO.- [Pythium insidiosum: identificação morfológica e molecular de isolados brasileiros.] Pythium insidiosum é um oomiceto pertencente ao Reino Stramenopila e agente etiológico da pitiose, uma doença infecciosa com riscos de morte. A pitiose é caracterizada pelo desenvolvimento de lesões crônicas sobre os tecidos cutâneos, subcutâneas, intestinal e ósseo em humanos e muitas espécies de animais. A identificação de $P$. insidiosum é importante, a fim de se obter um diagnóstico rápido e definitivo, bem como um tratamento eficaz. Este estudo relata a identificação de 54 isolados de $P$. insidiosum de cavalos, cães e ovelhas que apresentavam lesões compatíveis e suspeita clínicas de pitiose, provenientes de diferentes regiões do Brasil, através

\footnotetext{
${ }^{1}$ Received on September 12, 2011.

Accepted for publication on February 14, 2012.

${ }^{2}$ Laboratório de Pesquisas Micológicas, Departamento de Microbiologia e Parasitologia, Universidade Federal de Santa Maria (UFSM), Avenida Roraima 100, Santa Maria, RS 97105-900, Brazil. *Corresponding author: janio.santurio@gmail.com

${ }^{3}$ Instituto de Biologia, Universidade Federal de Pelotas (UFPel), Campus Universitário Capão do Leão s/n, Pelotas, RS 96010-900, Brazil.

${ }^{4}$ Departamento de Medicina Veterinária Preventiva, UFSM, Santa Maria, RS.

${ }^{5}$ Colegiado de Zootecnia, Universidade Federal do Vale do São Francisco, Rodovia BR 407, 12 Lote 543, Projeto de Irrigação Nilo Coelho s/n C1, Petrolina, PE 56300-000, Brazil.
}

de métodos morfológicos e moleculares. Através da PCR foi possível confirmar a identidade de todos os isolados brasileiros como sendo $P$. insidiosum.

TERMOS DE INDEXAÇÃO: Oomiceto, identificação, Pythium insidiosum, pitiose.

\section{INTRODUCTION}

The genus Pythium comprises several aquatic oomycetes classified in the kingdom Stramenipila, but only Pythium insidiosum is associated with pythiosis in animals and humans (Alexopoulos et al. 1996). The number of cases of the disease in these species has been increasing due to difficulties in treatment and risk of death of the affected species (Santurio et al. 2006). Thus, a rapid and safe identification is crucial to implement a differential diagnosis and effective treatment (Schurko et al. 2003a). The identification and classification of Pythium species are based on morphological and physiological characteristics; however, problems correlated to a lack of sexual structures and failure to induce in vitro zoosporogenesis are common (Schurko et al. 2003a). Thus the use of molecular biology assays has become an indispensable tool for an accurate identification of this pathogen (Grooters \& Gee 2002, Schurko et al. 2003a,b, 2004, Znajda et al. 2003, Vanittanakom et al. 2004, Pannanusorn et al. 2007, Berryessa et al. 2008, Bosco et al. 2008, 
Pesavento et al. 2008). This study reports the identification of isolates of $P$. insidiosum of horses, dogs and sheep from different regions in Brazil, which presented suspicious lesions of pythiosis, using morphological and molecular assays.

\section{MATERIALS AND METHODS}

Fifty-four samples of clinical pythiosis from horses, dogs and sheep were researched to perform the identification of the etiological agent. Samples were obtained in different regions of Brazil, 51 from kunkers of sick horses, one from sheep with oronasal lesions and two from dogs with gastrointestinal lesions that were suspicious of pythiosis. The morphological analyze was performed using zoosporogenesis assay previously described by Mendoza \& Prendas (1988). The molecular characterization was based on PCR assay using the specific primers (PI1 and PI2), prior employed in a nested-PCR assay by Grooters \& Gee (2002), to amplify a segment of the ITS1 region of rDNA. In this study the same primers were used to perform a singleplex PCR as an alternative in order to replace the nested-PCR assay and included some modifications. Total DNA was isolated according to the protocol described by Moller et al. (1992) and modified by Klassen et al. (1996). The DNA concentrations were determined using spectrophotometry. Amplifications were performed in $25 \mu \mathrm{l}$ reactions containing 50ng of DNA template, $3 \mu \mathrm{M}$ of each primer (Invitrogen), $100 \mu \mathrm{M}$ of dNTPs (Invitrogen), $2 \mathrm{mM} \mathrm{MgCl} 2,2.5 \mathrm{U}$ Taq DNA polymerase (Invitrogen), and $2.5 \mu \mathrm{l}$ of enzyme-buffer. All the amplifications were executed in an automatic thermocycler, and the PCR conditions were initial denaturation
(95을 3 min), followed by 32 cycler $\left(95^{\circ} \mathrm{C} / 30 \mathrm{~s}^{\circ}\right.$; $65^{\circ} \mathrm{C} / 30 \mathrm{~s}$ and $72^{\circ} \mathrm{C} / 30 \mathrm{~s}$ ) and a final extension of $10 \mathrm{~min}$ at $72^{\circ} \mathrm{C}$. Pythium insidiosum (ATCC 58637 and CBS 101155) were employed as positive controls in the PCR assay. Aspergillus fumigatus (ATCC 204305), Rhizopus arrhizus (LAPEMI 130809), Conidiobollus coronatus (ATCC 60925), and P.aphanidermatum (ATCC 26081) were utilized as negative controls. To verify the singleplex PCR accuracy we also performed a PCR for the internal transcribed spacer regions (ITS1, 5.8srRNA and ITS2), using the universal fungal primers ITS1 and ITS4 (White et al. 1990) to amplify P.insidiosum samples and negative controls and generated products were sent to DNA sequencing. The sequences obtained were analyzed and compared with others deposited in GenBank, confirming the identity of P. insidiosum.

\section{RESULTS}

Microscopically, all samples from clinical pythiosis in the morphological assay colonized the grass and developed zoosporangia and zoospores after 3 hours of incubation at $37^{\circ} \mathrm{C}$ in the induction medium (Fig.1A). In early stage the zoosporangia could not be differentiated from vegetative hyphae. At maturity, hyphal protoplasm flowed into a discharge tube and formed the zoosporangia. The zoosporangia were hyaline and globose (Fig.1B). Through progressive cleavage, zoospores were formed within the zoosporangia (Fig.1C). The motile zoospores mechanically broke the vesicle wall and released into the induction medium (Fig.1D).
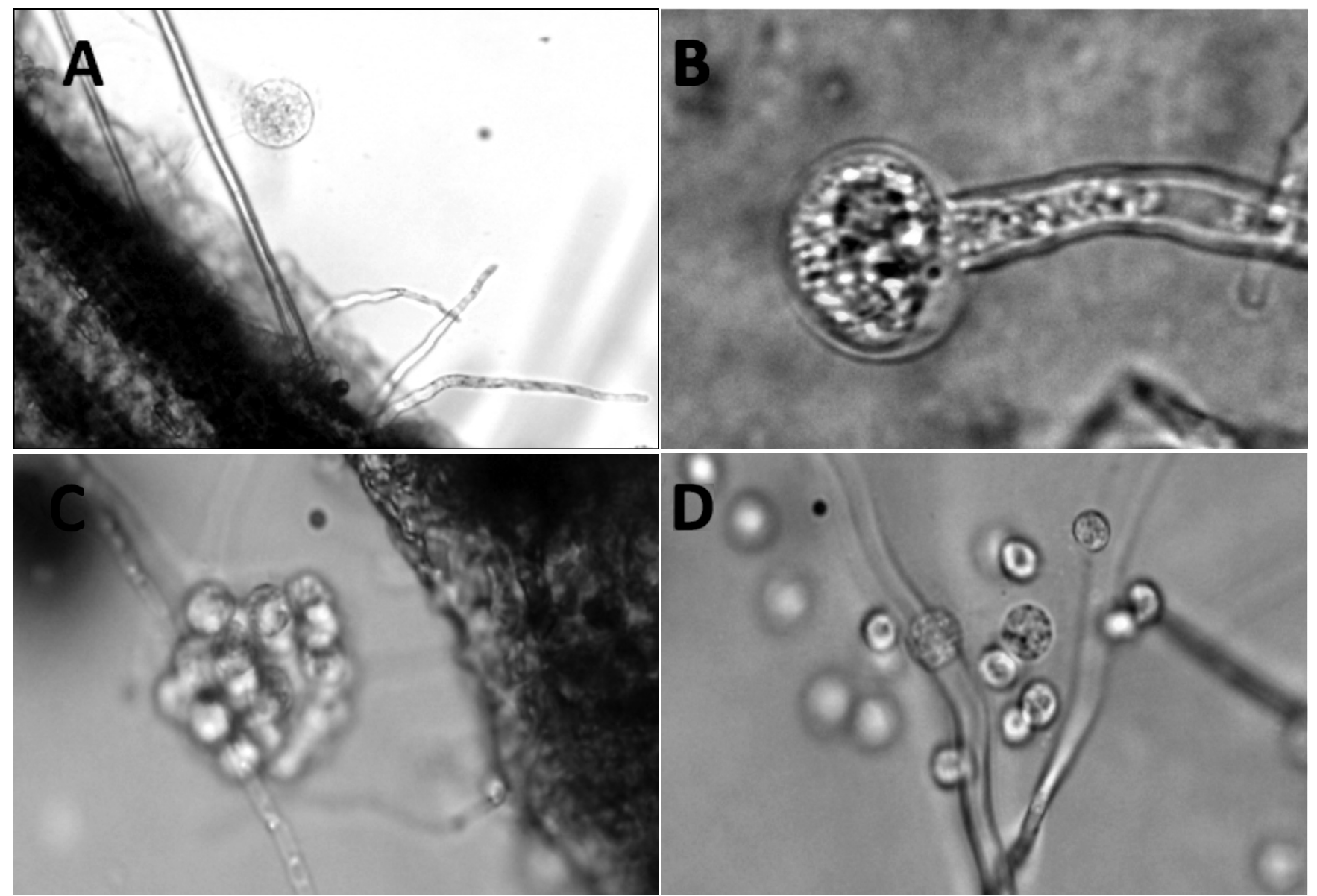

Fig.1. Morphological characteristics of Pythium insidiosum after 3 hours of incubation at $37^{\circ} \mathrm{C}$ in induction medium. (A) Grasses colonized for P. insidiosum hyphae. (B) Zoosporangium of P. insidiosum. (C) Zoospore formation of P. insidiosum within the zoosporangium. (D) Several motile zoospore released into the induction medium. 


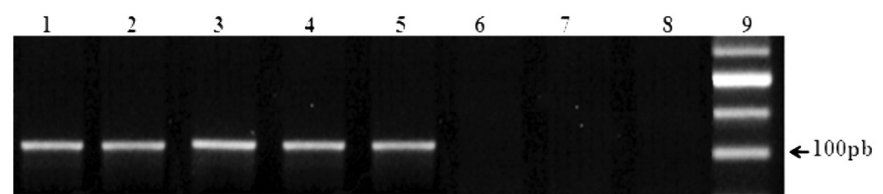

Fig.2. PCR amplification patterns of Pythium insidiosum isolated from horses, dogs and sheep. Amplicons were generated from a single PCR assay with $P$. insidiosum-specific primers (approx. $105 \mathrm{bp}$ ). Lines 1 and 2: P. insidiosum ATCC 58637 and CBS 101155, respectively; Lines 3, 4 and 5: Sample from horses, dogs and sheep, respectively; Line 6: Aspergillus fumigatus ATCC 204305; Line 7: Pythium aphanidermatum (ATCC 26081); Line 8: Ultra pure water; and Line 9 is a 100 bp DNA ladder (Ludwig Biotec ${ }^{\circledR}$, Brazil).

The zoospores were spherical to ovoid in form and bore two flagella. Once released from the vesicle, they continued to swim in a spiral or helical pattern for 10-15 min before encystment. The specific primers, PI1 and PI2, amplified the target region of ITS1 rDNA of P.insidiosum in the 54 isolates and the positive control samples, producing bands of 105-bp size. Amplicons were not visualized in the negative controls. Differences between the isolates from horse, dog and sheep were not observed (Fig.2) in 1.5\% agarose gel. DNA sequences of ITS1, 5.8srRNA and ITS2 regions ( 600-900-bp) were compared with sequences deposited in GenBank, confirming the molecular identity for all microorganisms used in this study.

\section{DISCUSSION AND CONCLUSION}

Traditional methods to identify different species of Pythium are based on morphological characteristics of zoosporangia, zoospores, oogonia and antheridia (Schurko et al. 2003a). In this study all 54 Brazilian isolates from clinical samples shared morphological characteristics of $P$. insidiosum as previously described by Mendoza et al. (1993) and Pereira et al. (2008), demonstrating that morphological analyses is useful for identification of this important pathogen. However, the implementation of this technique can be laborious, and it often fails to induce these structures in vitro. In addition, this procedure requires qualified professionals with experience to identify those structures (Wang \& White 1997, Schurko et al. 2003a). Besides the influence of environmental factors such as temperature, culture and isolation age can affect the morphological and physiological characteristics and impair the identification process (Schurko et al. 2003a). Furthermore, the morphological characteristics are often shared by other Pythium species as well as the genera Lagenidium and Phytophora (Grooters \& Gee, 2002). In such case, it is necessary to use methods more accurate to detect $P$. insidiosum. In the present study, we used a singleplex PCR assay with a pair of specific primers, previously described (Grooters \& Gee, 2002), which amplify a fragment containing a small portion of the ITS1 region of rDNA of $P$.insidiosum. All 54 isolates, which were previously identified by their morphological characteristics, amplified a band of the expected size, similar to those previously reported (Grooters \& Gee, 2002). The singleplex PCR tested confirmed the morphological identification of the 54 isolates from animal clinical samples as $P$. insidiosum. In addition the accurate diagnosis of clinical samples, the identification of Brazilian isolates of $P$. insidiosum originated of different animal species from diverse regions will allow future studies of evolution of this microorganism.

The morphological and molecular assays, employed in this study, were decisive and allowed to conclude that the Brazilian isolates of pythiosis from horse, dog, and sheep are $P$. insidiosum.

Acknowledgments.- To the Nacional Council for Scientific and Technological Development of Brazil (CNPq) for financial support.

\section{REFERENCES}

Alexopoulos C.J., Mims C.W. \& Blackwell M. 1996. Phylum Oomycota, p.683-737. In: Ibid. (Eds), Introductory Mycology. $4^{\text {th }}$ ed. Wiley, New York.

Berryessa N.A., Marks S.L., Pesavento P.A., Krasnansky T., Yoshimoto S.K., Johnson E.G. \& Grooters M.A. 2008. Gastrointestinal pythiosis in 10 dogs from Califórnia. J. Vet. Int. Med. 22:1065-1069.

Bosco S.M.G., Reis G.M., Theodoro R.C., Macoris S.A.G., Marques S.A., Macoris D.G. \& Bagagli E. 2008. Morphological and molecular characterization of an equine isolate of Pythium insidiosum and comparison with the first human isolate from the same geographic region. Med. Mycol. 17:1-9.

Grooters A.M. \& Gee M.K. 2002. Development of a nested polymerase chain reaction assay for the detection and identification of Pythium insidiosum. J. Vet. Intern. Med. 16:147-152.

Klassen G.R., Balcerzak M. \& DE Cock A.W.A.M. 1996. 5 S ribosomal RNA gene spacer as species specific probes for eight species of Pythium. Phytopathol. 86:581-587.

Mendoza L. \& Prendas J. 1988. A method to obtain rapid zoosporogenesis of Pythium insidiosum. Mycopathol. 104:59-62.

Mendoza L., Hernandez F. \& Ajello L. 1993. Life cycle of the human and animal oomycete pathogen Pythium insidiosum. J. Clin. Microbiol. 31:29672973.

Möller E.M., Bahnweg G., Sandemann H. \& Geiger H.H. 1992. A simple and efficient protocol for isolation of high molecular weight DNA from filamentous fungi, fruit bodies, and infected plant tissues. Nucleic Acids Res. 20:6115-6116.

Pannanusorn S., Chaiprasert A., Prariyachatigul C., Krajaejun T., Vanittanakom N., Chindamporn A., Wanachiwanawin W. \& Satapatayavong B. 2007. Random amplified polymorphic DNA typing and phylogeny of Pythium insidiosum clinical isolates in Thailand Southeast Asian. J. Trop. Med. Public. Health 38:383-391.

Pereira D.I.B., Santurio J.M., Alves S.H., Argenta J.S., Cavalheiro A.S. \& Ferreiro L. 2008. Zoosporogênese in vitro entre isolados do oomiceto Pythium insidiosum [In vitro zoosporogenesis among oomycetes Pythium insidiosum isolates]. Ciência Rural 38:143-147.

Pesavento P.A., Barr B., Riggs S.M., Eigenheer A.L., Pamma R. \& Walker R.L. 2008. Cutaneous pythiosis in a Nestling White-faced Ibis. Vet. Pathol. 45:538-541.

Santurio J.M., Alves S.H., Pereira D.I.B. \& Argenta J.S. 2006. Pitiose: uma micose emergente (Pythiosis: an emergent mycosis) Acta Sci. Vet. 34:1-14.

Schurko A., Mendoza L., De Cock A.W.A.M. \& Klassen G.R. 2003a. Evidence for geographic clusters. Molecular genetic differences among strains of Pythium insidiosum from Asia, Australia, and the Americas are explored. Mycology 95:200-208.

Schurko A., Mendoza L., Lévesque A., Désaulniers N.L., De Cock A.W.A.M. \& Klassen G.R. 2003b. A molecular phylogeny of Pythium insidiosum. Mycol Res. 107:537-544.

Schurko A.M., Mendoza L., De Cock A.W.A.M., Bedard J.E.J. \& Klassen G.R. 2004. Development of a species-specific probe for Pythium insidiosum and the diagnosis of pythiosis. J. Clin. Microbiol. 42:2411-2418. 
Vanittanakom N., Supabandhu J., Khamwan C., Praparattanapan J., Thirac S., Prasertwitayakij N., Louthrenoo W., Chiewchanvit S. \& Tananuvat N. 2004. Identification of emerging human-pathogenic Pythium insidiosum by serological and molecular assay-based methods. J. Clin. Microbiol. 42:3970-3974.

Znajda N., Grooters A. \& Marsella R. 2002. PCR-Based detection of Pythium and Lagenidum DNA in frozen and ethanol-fixed animal tissues. Vet Dermatol. 13:87-194.
Wang P.H. \& White J.G. 1997. Molecular characterization of Pythium species based on RFLP analysis of the internal transcribed spacer region of ribosomal DNA. Physiol. Mol. Plant Pathol. 51:129-143.

White T.J., Burns T. \& Lee S. 1990. Amplification and direct sequencing of fungal ribosomal RNA genes for phylogenetics, p.315-322. In: Innis M.A., Gelfand D.H., Sninsky J.J., White T.J. (Eds.), PCR Protocols: A guide to methods and applications. Academic Press, San Diego. 